\title{
Designing prototype model to support language development of autistic learners in early childhood
}

\section{Diseño de modelo prototípico para apoyar el desarrollo del lenguaje de los estudiantes autistas en la primera infancia}

\author{
Dilek Karahoca \\ Bahcesehir University. Istanbul. Turkey \\ dilek.karahoca@hes.bau.edu.tr \\ Adem Karahoca \\ Bahcesehir University. Istanbul. Turkey \\ adem.karahoca@eng.bau.edu.tr \\ Nesrin Özdemir \\ Bahcesehir University. Istanbul. Turkey \\ nesrin.ozdemir@hes.bau.edu.tr \\ Banu Karaosmanoğlu \\ Bahcesehir University. Istanbul. Turkey \\ banu.karaosmanoglu@hes.bau.edu.tr
}

\begin{abstract}
Children with autism generally show difficulty in both communication and in language learning. In this study, interactive interfaces designed to help children with autism to meet them with digital education. Interfaces are utilizable and colorful, makes a huge contribution on educational applications from the early childhood period on. Linguistic explanation feature was integrated to the interfaces on mobile platform by help of a tale to allow children to learn objects and their functions. It will play an active role with the development of language for early childhood period learners. In the audible streaming of the tale, by foregrounding the objective presentation, the equivalent of the object images were matched with the voices. By using the voice and object matching which is known as the natural method in language teaching, the actualization of the expected behavior is supported by providing individual freedom of iteration. The availability of the platform is tested with expertized user group and the level of platform usability was detected with system usability scale (SUS). It shows that usability and practicality of the prototype model has good effectiveness, efficiency and satisfaction base on expert evaluation.
\end{abstract}

\section{Key words}

Autism, early childhood, language development, mobile learning.

\section{Resumen}

Los niños con autismo generalmente muestran dificultad tanto en la comunicación como en el aprendizaje de idiomas. En este estudio, las interfaces interactivas diseñadas para ayudar a los niños con autismo a satisfacerlos con la educación digital. Interfaces son utilizables y coloridos, hace una enorme contribución en las aplicaciones educativas desde el período de la primera infancia en. Función de explicación lingüística se integró a las interfaces en la plataforma móvil con la ayuda de un cuento para permitir a los niños a aprender objetos y sus funciones. Jugará un rol activo con el desarrollo del lenguaje para los estudiantes de la primera infancia. En la transmisión audible del cuento, al poner en primer plano la presentación objetiva, el equivalente de las imágenes del objeto se emparejaron con las voces. Mediante el uso de la correspondencia entre voz y objeto que se conoce como el método natural en la enseñanza de lenguas, la actualización del comportamiento esperado se apoya proporcionando libertad de iteración individual. La disponibilidad de la plataforma se prueba con un grupo de usuarios expertizado y el nivel de usabilidad de la 
plataforma se detectó con la escala de usabilidad del sistema (SUS). Muestra que la usabilidad y practicidad del modelo prototipo tiene una buena eficacia, eficiencia y satisfacción basada en la evaluación de expertos.

\section{Palabras clave}

Autismo, niñez temprana, desarrollo del lenguaje, aprendizaje móvil.

\section{Introduction.}

Autism Spectrum Disorders (ASD) start before the age of three, lasts for a whole lifetime, damages social interaction and communication, also causes repeated and limited behaviors. Autism generates limitations in fields of interest, communicative disorders, problems in social interaction and developing social relations, stereotype and repetitive behaviors. Also, these limitations cannot be explained by mental disability (The American Psychiatric Association, 2013).

In the early childhood period, child makes important improvements in language development and starts using the language as a social acknowledgement. Depending on the sociocultural structure that is lived in, they interact with different signs of images and these are started to be used in the child's world.

When autism affected children's, they are not attempting event initialization, remain passive, motionless or they are interested only in answering the adult's requests, and they have low level of initialization with low efficiency (Selimoğlu, Özdemir, Töret, \& Özkubat, 2015).

In this stage, expected language and communication functions do not occur as desired, or expected process development does not emerge. In early diagnosed autism cases, on the level of cognitive development for the sustainability of language and communication abilities, support given by mobile devices or computers is crucial in learning the symbols of the language. Interaction with software tool for language and symbol matching has effects on fluent language learning and provide sustainability in education (Zapata, 2010). So in software tool, with the support of the family and through the role of the system partner role being active, desired efficacy will be provided from designed system and will contribute a non-disabled environment consciousness.

\subsection{Problem of the Study.}

Every child tries to adapt for the sake of completeness with the life during their first years. This adaptation process related improvement, accelerates in three- five years age duration and process of learning improves fast. But some children face some difficulties related to adaptation process application in their early years of life, and during this process they need more intense and direct responses (Stanton-Chapman, Denning and Jamison, 2008). Diagnosing children with autism and finding solutions to their adaptation problems with life regarding their needs are the priorities to handle.

The basic problems of the families of autistic children are communication disorders and non-progressive language in communication. They can observe the syndrome by detecting different behaviors such as being unresponsive in dialogs or repeated language

Designing prototype model to support language development of autistic learners in early childhood. Dilek Karahoca, Adem Karahoca, Nesrin Özdemir and Banu Karaosmanoğlu. 
usage, being unable to catch the speech rhythm, wrong usage of personal pronouns etc. and problems in learning the language.

Learners with autism are extremely insistent on the protection of uniformity. It is known with the recent studies that the protection of uniformity obsession, affects child's progress of language abilities. Children with autism commonly show their insistence about using the same word or word group, by asking standard questions and expecting same responses to be given (Bodur, Soysal, İșeri, Şenol, 2006).

In another study, Behavioral Training for Children with Autism Program Tracking Tool (Otizmli Çocuklar İçin Davranışsal Eğitim Programı İzleme Aracı OÇİDEP-İZ) was designed. In regards of critical basic abilities for children with autism, to find out their level before entering the OÇIDEP program; it is repeat the same evaluation and match with previous levels, to see their proceeds the learners show. In OÇİDEP-İZ program language mimicking, oral recipient language and oral expressive language abilities are concentrated on. It is monitored that the family has opinions that OÇIDEP program helping their children's development but the program needs to be applied by paying attention to specific points (Aslan, 2014).

The children who are affected with autism spectrum disorder in their early childhood period have to be supported by parents for cognitive and linguistic development. Otherwise, when the words learned by the child are not repeated, the desired process of language development is being delayed. It is remarkable that there are few mobile platforms to edit and use linguistic events that can be repeated media independent in mother language learning. Another issue is, there are so few domestic applications for children with autism, and prototype offerings are needed in this area even though they are of foreign origin (Hanayl, Serbest and Ürekli, 2015). Also on mobile devices, needbased individual designs are needed for this group of children.

\subsection{The purpose of the study.}

With this mobile prototype model; it is aimed to create the event of story with pictures that supports language development and to learn language symbols in word basis to use them in sentences for learners with autism in their early childhood. Depending on the flow of story, it is also defined as the basic aim to create individual word learning levels and carrying the level developments to upper level. We can summarize the main purpose of the study as supporting the language acquisition skills of autistic children by using interactive software tool.

\subsection{The method of the study.}

For the study, an observation has been done with autistic children and teachers were interviewed about autistic children for 2014-2015 academic year in Tohum Autism Foundation. Autistic children were almost 7-8 ages.

First of all, requirements analysis phase has been fulfilled regarding the language development needs of autistic learners. Interviews and observations were carried out with advisors during requirements analysis.

Designing prototype model to support language development of autistic learners in early childhood. Dilek Karahoca, Adem Karahoca, Nesrin Özdemir and Banu Karaosmanoğlu. 
Autistic students learn a new object every day with their teachers and perform repetitive dubbing exercises. To make this event continuous for language development and for word learning, also the family in the house environment is included to the education. In these workouts, eye contact and repetition of voices are based on.

Learners, who complete this stage, are taken to group workouts and proceed to in-class academic educations. During group events, a mobile event starter tool is being used. At first, learner chooses one of colorful event cards and then starts by making the event card read in the program named as "Creator". When the event is completed successfully, the learner gets awarded.

Among observed groups, the needs of the learners; after passing some of educational steps, learners who show changes in expected behaviors, and has actualized linguistic development with in group education support, also the needs of learners have been detected by one-to-one interviews with their trainers.

The prototype model which was designed depending on the needs of the user profile, the functional necessities can be classified as such: User's being a member of the system, user's taking a personal assistant support to execute his/her own user activities, sending error messages when user cannot make the desired connection, being able to make the alliteration for the words selected within the story and being able to create user records and evaluate them, being able to take and evaluate word examinations. Amongst the non-functional needs of the designed system, achieved language development level privacy for each user takes place as a fundamental.

\section{Modelling user interfaces.}

In this section, designed and developed user interfaces and its functionalities have been given it detail. Usage and user scenarios are given in software engineering perspective. Case scenarios are basic elements of the Unified Modelling Language (UML). By defining case scenarios, any process can be given in end user and system perspective.

\subsection{Case scenarios.}

Case modelling and possible alternative scenarios regarding different requirements is defined for the user as such: login to the system, accessing to the content, accessing to quiz, accessing to stories.

\section{Case Scenario for login to the system}

1. User runs the application.

2. User enters the username.

3. User enters to the system.

\section{Case Scenario to reach the content}

1. User login to the system.

2. User selects "content".

3. User selects one of the topics.

4. The content of the chosen topic is loaded to the user's device.

Designing prototype model to support language development of autistic learners in early childhood. Dilek Karahoca, Adem Karahoca, Nesrin Özdemir and Banu Karaosmanoğlu. 
5. User selects one or both of the reading or listening material from the content.

\section{Case Scenario to quiz}

1. User login to the system.

2. User selects "Quiz".

3. User selects one of the topics to examine her.

4. Selected topic is loaded to the user's device.

5. First, questions and answering options are shown. The question can also be a gap filling one.

6. User selects an answer or fills the gap. If answered wrong, the correct one is shown.

7. To monitor other questions, user taps/clicks on "Next" button.

8. At the end of the examination, system gives an evaluation printout.

\section{Case scenario for stories}

1. User login to the system.

2. User selects "Stories" section.

3. The story that the user selects is played.

4. Previously selected words in story are dubbing again.

5. Repeat words that are saved for the user in the story are saved.

6. The number of correctly vocalized words in the user selected story is shown.

7. User logs out from the system.

This designed system will provide improvement for autistic learners who have language development in two different levels. Voice repetition records will product informative report about available level in spelling ability and the achieved level. Also, with repetitive sentences in the story, grammar structure of the language will be supported up to be learned. Sentence and word based repeated things, match at the same time with actor and objects in the monitor. With alternative word repetition, depending on the story flow, vocalization about the related object or the actor will be given first so the matching with the object will be provided.

The educational method within the layout is based on role play, and picture with visual activities to be created. Designing different and the same activities inside a story, affects the learning moments. The environment which was designed to provide social connectivity in this kind of designs is to have features convert able to multiple user systems.

The real factor for autistic learner to benefit from digital systems which provide support for learning in digital environment depending on different social status in different levels is to provide attendance. The attendance in digital environment comes to the forefront in regards of being ready to learn. At the very next step, it is important to present the interest times according to the necessities. Within the time that the interest is shown; gaining in the sense of cognitive flexibility for the learner, are important for the efficiency of the designed environment. Also in similar designs, starter cards and voice commands are being used to start or to trigger the event. When the digital environments that are designed for this reason are used in academic environments; expected benefit supports the communication structure. When mimics with low functional autistic kids, 
sign language, and oral approach types are reiterated with events in academic environment, communication levels can be moved to a desired level (Llaneza, Deluke, Batista Crawley, Christodulu and Frye, 2010). Picture Exchange Communication System (PECS), is a low-tech and an effective audible tool for low functional autistic kids in class or out class. PECS which is known as an audible book tool is also known as DynaVox or Dynamate. It is in shape of a laptop with a little touchscreen. Pages depending on the interest of learners have been shaped beforehand. Commands, features and features to download images that are used in pages, are specially designed.

In PECS enabled pictures that children have interest in, are selected with priority for the "entrance to communication" exam to be created. By giving information about these pictures, a new door is being opened into the communication link. In the prototype design suggestion, which is in scope of study; by visualizing structural mechanism of teaching event in PECS, it can be used both in and out of the academic environment through mobile devices.

In the system we designed; matching, vocalization, learning of names, and taking the examinations event, can both be applied as individual activity and in classroom activity. Below, some interface mock-up examples are shown from some events.

In Figure 1, one user can login to the system. First one for object mapping, second one for lets learn for our body and last one is storytelling. Figure 2 shows the storytelling interface. When user clicks the interface, dog starts to tell "I am a dog. I am an animal Dogs pound. " as given in figure 3. In storytelling interface, when user clicks the quiz, the question is asked to the user as "Which one is dog?" and if the answer is given in right way, user gets feedback for the answer as given in figure 4-5.

Figure 1.System login interface.

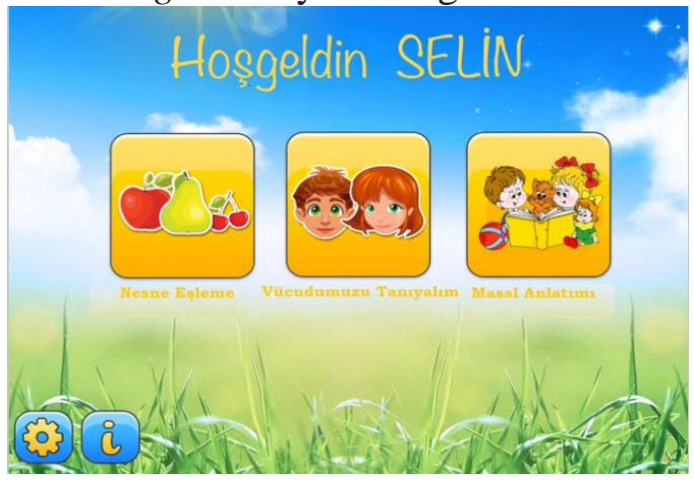

Figure 3. Storytelling interface.
Figure 2. Story login interface.

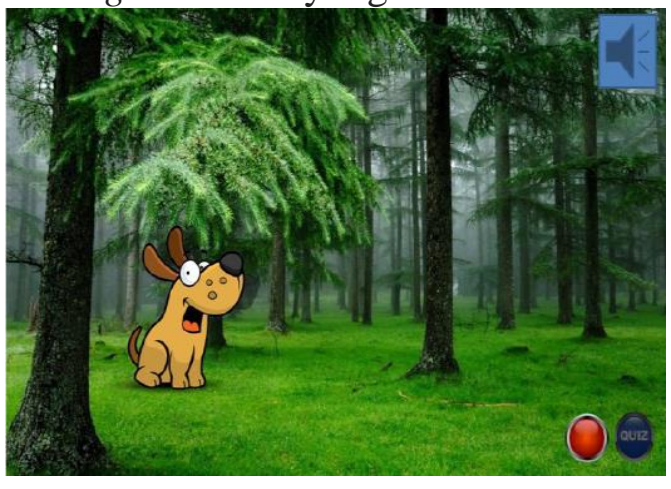

Figure 4. Asset defining interface (Which one is dog?). 

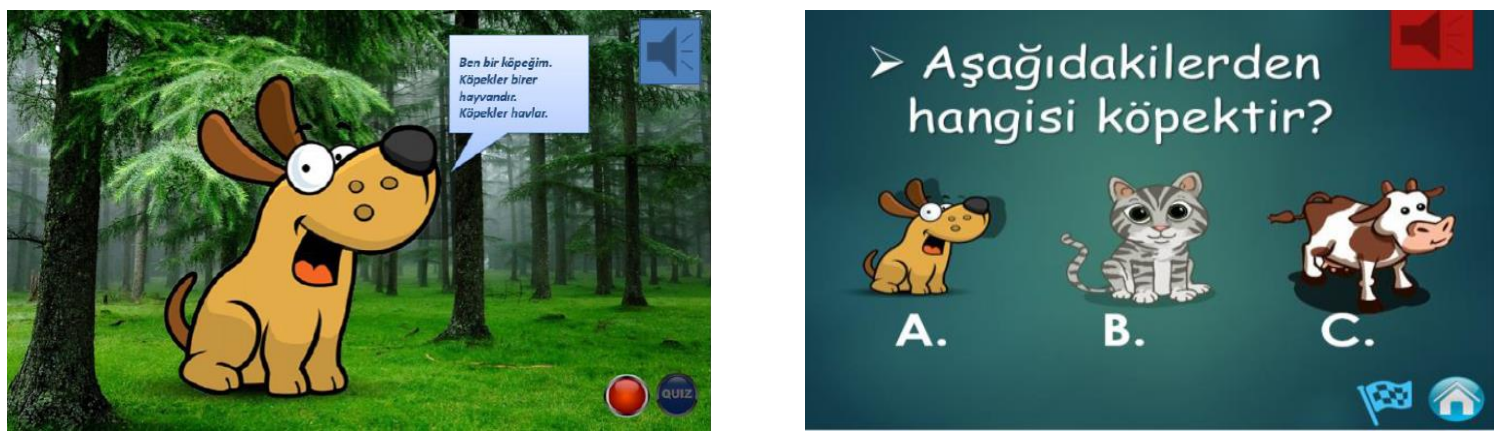

Figure 5. Asset defining interface (Which one is $\operatorname{dog}$ ?).

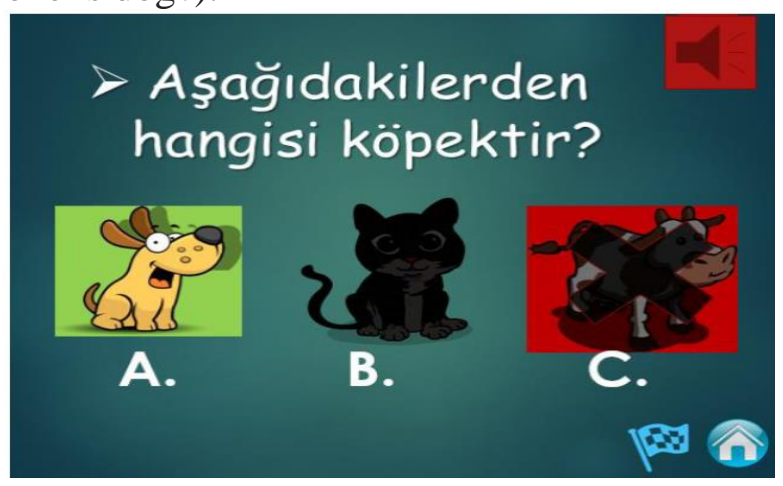

\section{Results.}

The usability of the prototype model was tested by System Usability Scale (SUS) along with 4 experts, two software engineers and two education technologists. SUS has 10 items inside for usability evaluation of software systems (Brooke, www.usability.gov).

Dimensions in system usability have been considered as: efficiency, productivity and satisfaction. On efficiency dimension, it is successfully finding the files within the system. On productivity dimension, it is the effort for finding the objects inside the system and the satisfaction to get from the usage of the system. System Usability Scale is a valid test that has been referred over 1300 articles. According to the SUS manual, average percentile rank of system has to be greater than 68. Participants, found the usage extremely easy. After every participant replied 10 items, average usability of the system score was calculated near 80 percent. Users have evaluated system usability and the access of user into the scopes.

\section{Conclusions.}

Supporting daily life communication skills with mobile technologies for autistic learners is important for disabled individuals to get a continuous education. With the active usage of this application, it makes the application popular by becoming a part of infamily education process. Mobile environments, in meaning of surpassing limitations about starting the event, provide easy usage efficiency. About special educational applications for disabled individuals, the usability and the mobility of applications, in the meaning of education to reach its scopes, affects the sustainability. So, popularizing

Designing prototype model to support language development of autistic learners in early childhood. Dilek Karahoca, Adem Karahoca, Nesrin Özdemir and Banu Karaosmanoğlu. 
the designed prototype suggestion, differentiating it with regards to different language development levels, ensures the sustainability of the workout. The language development contribution to be applied to autistic children in their early childhood period is a starting point to minimize their problems of adapting to life. The any moment of accessibility of information technologies in surrounding education world, has the qualification of awareness in developing the already gained language for this group of learners.

Presentation of the article: February 15, 2017

Date of approval: March 15, 2017

Date of publication: March 31, 2017

Karahoca, D., Karahoca, A., Ozdemir, N. y Karaosmanoğlu, B. (2017). Designing prototype model to support language development of autistic learners in early childhood. RED. Revista de Educación a Distancia, VOL. Consultado el (dd/mm/aaaa) en http://www.um.es/ead/red/

This research did not receive any specific grant from funding agencies in the public, commercial, or not-for-profit sectors.

\section{References}

American Psychiatric Association. (2013). Diagnostic and statistical manual of mental disorders (DSM-5®). American Psychiatric Pub.

Aslan, Y. G. (2014). Autism Spectrum Disorder Experiences And Perceptions of Teacher Candidates In Teacher of Mentally Handicapped Program Kastamonu Education Magazine, 22(3), 869.

Bellini, S., Peters, J. K., Benner, L., \& Hopf, A. (2007). A meta-analysis of schoolbased social skills interventions for children with autism spectrum disorders. Remedial and Special Education, 28(3), 153-162.

Bodur Ş, Soysal AŞ, İşeri E, Şenol S. (2006). Early Symptoms and Diagnosis of Autistic Disorder. Turk J Child Adolesc Ment Health, 13(3): 130-136.

Brooke, J., System Usability Scale (SUS), Consultado el 3/01/2017 en https://www.usability.gov/how-to-and-tools/methods/system-usability-scale.html

Cevahir, H., \& Özdemir, M. (2015). Mobile Learning Researches Towards Individuals with Disabilities: A Content Analysis Between 2005 and 2015. İstanbul Açık ve Uzaktan Eğitim Dergisi (AUZED), 1(2).

Hanaylı, M., Serbest, S., \& Ürekli, T. (2015). Otizmli Çocukların Sosyal Becerilerini Geliştirmeye Yönelik Android Uygulaması(Android App for Developing Social

Designing prototype model to support language development of autistic learners in early childhood. Dilek Karahoca, Adem Karahoca, Nesrin Özdemir and Banu Karaosmanoğlu. 
Skills of Autistic Children). XVII. Akademik Bilişim Konferansı(Academic Informatics Conference). Eskişehir: Anadolu Üniversitesi.

Llaneza, D. C., Deluke, S. V., Batista, M., Crawley, J. N., Christodulu, K. V., \& Frye, C. A. (2010). Communication, Interventions, And Scientific Advances In Autism: A Commentary. Physiology \& Behavior, 100(3), 268-276.

Pobbe, R. L., Defensor, E. B., Pearson, B. L., Bolivar, V. J., Blanchard, D. C., \& Blanchard, R. J. (2011). General and social anxiety in the BTBR T+tf/J mouse strain. Behavioural Brain Research, 216(1), 446-451.

Selimoğlu, Ö. G., Özdemir, S., Töret, G., \& Özkubat, U. (2013). An examination of the views of parents of children with autism about their experiences at the postdiagnosis period of autism. International Journal of Early Childhood Special Education, 5(2), 129-167.

Stanton-Chapman, T. L., Denning, C. B., \& Jamison, K. R. (2008). Exploring the effects of a social communication intervention for improving requests and word diversity in preschoolers with disabilities. Psychology in the Schools, 45(7), 644664.

Zapata, M. (2010). Estrategias de evaluación de competencias en entornos virtuales de aprendizaje. RED. Revista de Educación a Distancia. Sección de Docencia Universitaria en la Sociedad del Conocimiento. Número 1. Consultado el 11/03/2017 en

http://www.um.es/ead/reddusc/1. https://www.um.es/ead/reddusc/1/eval_compet.pd $\mathrm{f}$

Designing prototype model to support language development of autistic learners in early childhood. Dilek Karahoca, Adem Karahoca, Nesrin Özdemir and Banu Karaosmanoğlu. 